Research article

\title{
INVESTIGATION ON CANINE PARVOVIRUS CIRCULATION IN DOGS FROM SICILY (ITALY) BY BIOMOLECULAR ASSAY
}

\author{
PURPARI Giuseppa ${ }^{1}$, MIRA Francesco ${ }^{1}$, Di BELLA Santina ${ }^{1}$, Di PIETRO Simona ${ }^{2}$, \\ GIUDICE Elisabetta ${ }^{3 *}$, GUERCIO Annalisa ${ }^{1}$
}

${ }^{1}$ Istituto Zooprofilattico Sperimentale della Sicilia “A. Mirri”, Palermo, Italy; ${ }^{2}$ Department of Veterinary Sciences. University of Messina. Polo Universitario dell'Annunziata, Messina, Italy; ${ }^{3}$ Department of Chemical, Biological, Pharmaceutical and Environmental Sciences, University of Messina, Italy.

(Received 07 March, Accepted 25 December 2017)

Canine parvovirus type-2 (CPV-2) is a DNA virus that causes a very common worldwide diffused infectious disease in dogs. Since its appearance, the CPV-2 evolved generating novel genetic and antigenic variants $(\mathrm{CPV}-2 \mathrm{a} / 2 \mathrm{~b} / 2 \mathrm{c})$ which are distributed throughout the world. In the present study, the frequency of CPV-2 in a canine population in Sicily (Italy) was investigated, using a polymerase chain reaction (PCR) for a fragment of the VP2 gene. Out of a total of 673 samples from 370 dogs, submitted to the laboratory from July 2009 to August 2015, 265 samples (39.38\%) were positive and these were further analyzed by restriction fragment length polymorphism (RFLP) and DNA sequence analysis. A high prevalence of the CPV-2c variant $(79.56 \%$ of $\mathrm{CPV}$ 2 positive dogs) was observed in this survey, underlining that this type of CPV field isolate is prevalent circulating in Sicily. Sequence and phylogenetic analysis showed a close relationship with CPV-2a and CPV-2c strains from Europe and non-European countries. Considering that $\mathrm{CPV}-2 \mathrm{c}$ is reaching a worldwide distribution and that this variant is also affecting vaccinated dogs, efforts should be made towards the development of new CPV vaccines.

Key words: polymerase chain reaction, canine parvovirus, virus isolation

\section{INTRODUCTION}

A variety of infectious diseases can affect the dogs and their adverse effects on health have been repeatedly documented [1-3]. Canine parvovirus (CPV) causes a very common worldwide diffused infectious disease in dogs. This agent is highly pathogenic and contagious and it is one of the leading causes of disease in farm, kennel and shelter dogs. Even if the main clinical manifestation of CPV infection is gastroenteritis, this virus also causes a systemic infection. CPV is a small nonenveloped single-stranded negative-sense DNA virus, member of the genus Parvovirus, family Parvoviridae. The genome is of about 5200 nucleotides (nt) in length and has two open reading frames

*Corresponding author: e-mail: egiudice@unime.it 
(ORF) that encode for non-structural (NS) and structural viral proteins (VP) [4]. The CPV capsid is a $25 \mathrm{~nm}$ diameter icosahedron made up of a combination of two proteins, VP1 and VP2, formed by alternative splicing from the same RNA [5]. Two genetically and antigenically distinct CPVs are known: CPV-1 and CPV-2 [6,7]. CPV2 is the cause of a very serious and often fatal hemorrhagic gastroenteritis especially in dogs up to 1 year of age. Rarely, this serotype can cause fatal myocarditis in very young puppies less than three months of age. CPV-2 belongs to the genus Parvovirus, along with feline parvovirus (FPV), feline panleukopenia virus (FPLV), raccoon dog parvovirus (RDPV) and blue fox parvovirus (BFPV) [8,9]. These viruses show a very similar genome up to $98 \%$ [10] and it is possible to distinguish them genetically from canine parvovirus type 1 (CPV-1), which causes neonatal death in puppies [11-13] and latent infection in older subjects.

Over the years CPV-2 has evolved and new variants appeared: CPV-2a, CPV-2b [1417].

The new antigenic variant CPV-2c has been reported in Italy for the first time in 2001 $[18,19]$ and since then it has also been identified in other countries [20-25].

Indeed, although these single-stranded viruses have a DNA genome, their rate of nucleotide substitution is closer to that of RNA viruses than to that of doublestranded DNA viruses. Infected dogs shed viruses in feces for a long period (40 days); so, the fecal contagion is the most diffuse way for maintaining the infection. The use of proper vaccination is a precious help in controlling this disease.

In the last years, the methods for DNA-based analysis showed an increasing importance in veterinary diagnostics [26,27] because of their high sensibility and specificity. The main molecular diagnostic methods utilized are: Polymerase Chain Reaction (PCR), Real-Time PCR and quantitative Real Time PCR (qPCR). The aim of the study is to report the results of an epidemiological investigation on canine parvovirus circulation in a large dog population in Sicily by molecular assays, as rapid and highly accurate diagnostic tools.

\section{MATERIAL AND METHODS}

\section{Samples}

Clinical specimens were collected in the Virology Laboratory at Istituto Zooprofilattico Sperimentale della Sicilia "A. Mirri” (Sicily, Italy) and were examined for the detection of CPV-2. The samples had been submitted from July 2009 to August 2015 for testing of different canine viral pathogens and stored at $-80^{\circ} \mathrm{C}$ until analysis. The study was conducted on 673 samples derived from 370 living and dead dogs, which had suffered from gastrointestinal disorders. The dogs enrolled in this study came from veterinarian clinics and kennels, both public and private and they were heterogeneous for age, sex and breed. Informed consent has been obtained for client-owned animals included in this study. Blood samples, swabs and stool samples were taken from 224 live symptomatic subjects, while tissue samples such as intestine, lymph nodes, liver, spleen and heart were taken from 146 dead patients. 
Blood sampling: Blood samples were collected via jugular or cephalic venipuncture into EDTA tubes. The samples were then stored at $4^{\circ} \mathrm{C}$ and analyzed within 24-48 hours after collection.

Biomolecular analyses were carried out on $100 \mu$ l of sample by means of nuclease-free tube.

Fecal samples and rectal swabs: Stool swabs received at the laboratory were chilled $\left(4^{\circ} \mathrm{C}\right)$ in a suitable transport medium (Minimum Essential Medium Eagle (EMEM), Lonza, BioWhittaker, VWR, Pennsylvania), supplemented with antibiotic and antifungal drugs $(1000 \mathrm{U} / \mathrm{ml}$ penicillin $\mathrm{G}$ sodium salt, $1 \mathrm{mg} / \mathrm{ml}$ streptomycin sulfate, $2.5 \mu \mathrm{g} /$ $\mathrm{ml}$ amphotericin B; PAA Laboratories $\mathrm{GmbH}$, Austria). Test tubes, hermetically sealed within 24-48 hours after collection and stored at $4^{\circ} \mathrm{C}$, were used. Fecal samples were also transported after being stored at $4^{\circ} \mathrm{C}$ and after arrival at the laboratory they were homogenized $(10 \% \mathrm{w} / \mathrm{v})$ in the same above cited transport medium. Later, $200 \mu \mathrm{l}$ of experimental material were put in a nuclease-free tube, in order to carry out biomolecular assays.

Organs: An organ was considered suitable to be analyzed when it reached the laboratory in appropriate airtight containers, with no signs of deterioration or decomposition, cooled $\left(4^{\circ} \mathrm{C}\right)$ or stored at $-20^{\circ} \mathrm{C} /-80^{\circ} \mathrm{C}$. Biomolecular assays were carried out on $25 \mathrm{mg}$ of homogenized and processed sample, as recommended by the extraction kit instructions.

\section{Laboratory analyses}

In order to identify the presence of CPV-2, all samples were assessed by means of biomolecular analysis. The isolated viral strains were characterized by PCR based Restriction Fragment Length Polymorphism analysis (PCR-RFLP) and sequencing.

\section{Biomolecular assays}

$D N A$ extraction and PCR amplification: The extraction of DNA was carried out, according to the manufacturer's instructions (DNeasy Blood \& Tissue Kit ${ }^{\circledR}$, Qiagen Inc., Hilden, Germany). Two PCR assays specific for VP2 capsid protein were used in order to search for CPV-2. The procedures of amplification were performed using two pairs of primers targeting two different regions of the VP2 gene, which gives rise to two amplified products of distinct size (Table 1). The first pair of primers consists of primers indicated by the abbreviation 555for and 555rev, respectively [18]. The second pair is indicated by the abbreviation VP2-850-Forward and VP2-1550-Reverse [23]. The PCR reactions were performed using a commercial kit (Go Taq DNA Polymerase, Promega Corp. Madison, WI) in a final volume of $50 \mu \mathrm{l}$, containing: $10 \mu \mathrm{l}$ of $5 \mathrm{X}$ buffer, $0.25 \mu \mathrm{l}(1.25 \mathrm{U})$ of DNA Polymerase, $1 \mu \mathrm{l}$ of $25 \mathrm{mM} \mathrm{MgCl}_{2}, 1 \mu \mathrm{l}$ of $10 \mathrm{mM}$ deoxynucleotide triphosphate (dNTP) mixture (dATP, dCTP, dGTP, dT'TP), $0.5 \mu l$ of each primer $(50 \mu \mathrm{M}), 31.75 \mu \mathrm{l}$ of Nuclease-free water and $5 \mu \mathrm{l}$ of DNA. The thermal 
conditions consisted of 1 cycle of denaturation at $94^{\circ} \mathrm{C}$ for $1 \mathrm{~min}$ and 40 cycles of denaturation at $94^{\circ} \mathrm{C}$ for $30 \mathrm{~s}$, annealing at $55^{\circ} \mathrm{C}$ for $1 \mathrm{~min}$ and polymerization at $72^{\circ} \mathrm{C}$ for $1 \mathrm{~min}$, followed by a final extension at $72^{\circ} \mathrm{C}$ for $10 \mathrm{~min}$. Then, $10 \mu \mathrm{l}$ amounts of PCR products were detected by $2 \%$ agarose gel electrophoresis, and visualization under UV light after bromide ethidium staining. The presence or absence of an electrophoretic band from the by amplification produced DNA fragment was checked. The test was considered valid if the positive control had a band of 583 bp (Primers: "555for" and "555rev") or 700 bp (Primers: "VP2-850-Forward" and "VP2-1550-Reverse"). The negative control showed no band. The sample was considered positive if it showed the same band as the positive control.

Table 1. Polymerase Chain Reaction (PCR) primers for Canine Parvovirus (CPV)-2 detection

\begin{tabular}{lllc}
\hline $\begin{array}{l}\text { Primers } \\
\text { (couple I) }\end{array}$ & Sequence & Position & Amplicon \\
\hline 555for & 5'-CAGGAAGATATCCAGAAGGA-3' & $4003-4022$ & 583 bp \\
555rev & 5'-GGTGCTAGTTGATATGTAATAAACA-3' & $4585-4561$ & \\
$\begin{array}{l}\text { Primers } \\
\text { (couple II) }\end{array}$ & Sequence & Position & Amplicon \\
VP2-850-Forward & 5'-GAGCATTGGGCTTACCA-3' & $850-866$ & 700 bp \\
\hline VP2-1550-Reverse 5'-GCAAGATGCATCAGGATC-3' & 1533-1550 & \\
\hline
\end{tabular}

RFLP analysis: Restriction analysis (PCR-RFLP) was performed on amplicons of $583 \mathrm{bp}$ and $700 \mathrm{bp}$ of PCR positive samples in order to identify CPV-2c strains. For this purpose, the enzyme (MboII enzyme, Promega Corp. Madison, WI) specific for GAAGA sequence at 4062-4066 nt of the CPV-2c strain was employed [18,23].

Sequencing: One CPV-2 positive sample from 30 positive tested dogs, selected on the basis of different geographical location and origin, were further amplified by PCR using specific primers (P1 and VPR) for sequencing (Table 2), which amplify a region of $1745 \mathrm{bp}$ inside the VP2 gene [7,28,29]. The PCR reaction was performed with a commercial kit ${ }^{\mathrm{d}}$ in a final volume of $50 \mu$ l containing: $10 \mu \mathrm{l}$ of $5 \mathrm{X}$ buffer, $0.25 \mu \mathrm{l}$ $(1.25 \mathrm{U})$ of DNA Polymerase, $1 \mu \mathrm{l}$ of $25 \mathrm{mM} \mathrm{MgCl}, 1 \mu \mathrm{l}$ of $10 \mathrm{mM}$ deoxynucleotide triphosphate (dNTP) mixture (dATP, dCTP, dGTP, dTTP), $1 \mu$ l of each primer $(20 \mu \mathrm{M})$, $30.75 \mu \mathrm{l}$ of nuclease-free water and $5 \mu \mathrm{l}$ of DNA. The thermal conditions consisted of 1 cycle of denaturation at $94^{\circ} \mathrm{C}$ for 2 min and 40 cycles of denaturation at $94^{\circ} \mathrm{C}$ for $30 \mathrm{~s}$, annealing at $45^{\circ} \mathrm{C}$ for $2 \mathrm{~min}$ and polymerization at $72^{\circ} \mathrm{C}$ for $2 \mathrm{~min}$, followed by a final extension at $72^{\circ} \mathrm{C}$ for $10 \mathrm{~min}$. Then $10 \mu \mathrm{l}$ amounts of the PCR products were detected by $2 \%$ agarose gel electrophoresis and visualization under UV light after bromide ethidium staining. Finally PCR products were purified (IllustraÔ GFX PCR DNA and Gel Band Purification Kit, GE Healthcare Life Sciences, Amersham Place Little Chalfont Buckinghamshire, UK). The purified amplicons were sent with 2 primers reverse (VPR and 41-FOX2) (Table 2) to a commercial firm for sequencing, 
as previously reported [29,30]. According to an overlapping strategy, sequences were assembled using BioEdit ver 7.2.5 software [31]. Assembled nucleotide sequences were submitted to the BLAST program (http://blast.ncbi.nlm.nih.gov/Blast.cgi) to search related sequences in GenBank. Nucleotide (nt) and the deduced amino acid (aa) sequences were aligned. Multiple sequence alignment analysis with sequences retrieved from GenBank was performed (ClustalW, Conway Institute UCD, Dublin). Phylogenetic analysis based on the partial length VP2 gene sequences was performed with MEGA5 software [32] using the Neighbor-Joining method, according to the substitution model Tamura 3-parameter with a discrete Gamma distribution $(+\mathrm{G})$ (bootstrap 1000 replicates). In the construction of the phylogenetic tree, homologous sequences have not been included.

Table 2. Polymerase Chain Reaction (PCR) primers for Canine Parvovirus (CPV)-2 sequencing

\begin{tabular}{lll}
\hline Primers & Sequence & Position \\
\hline P1-Forward & 5'-ATGAGTGATGGAGCAGTTC-3' & $2788-2807$ \\
VPR-Reverse & 5'-TTTCTAGGTGCTAGTTGAG-3' & $4512-4530$ \\
41-FOX2-Reverse & 5'-GCCCTTGTGTAGACGC-3' & $3825-3840$ \\
\hline
\end{tabular}

\section{Virus isolation}

All specimens PCR-positive for CPV-2 were processed for the virus isolation and inoculated on permissive cell lines A72 (Canine tumor) [33]. A72 cells were grown using a medium (Minimum Essential Medium Eagle (EMEM), Lonza, BioWhittaker, VWR, Pennsylvania) supplemented with 10\% fetal bovine serum (Fetal Bovine Serum, EuroClone S.p.A., Pero (MI), Italy) and an antibiotic and antifungal solution $(100 \mathrm{U} / \mathrm{ml}$ penicillin $\mathrm{G}$ sodium salt, $0.1 \mathrm{mg} / \mathrm{ml}$ streptomycin sulfate, $0.25 \mu \mathrm{g} / \mathrm{ml}$ amphotericin B; PAA Laboratories GmbH, Austria). The samples were homogenized (10\% w/v) in the same previously mentioned transport medium. Extracts were used to inoculate cell monolayers in the mitotic phase, left in contact for $30 \mathrm{~min}$ at $37^{\circ} \mathrm{C}$ and $5 \% \mathrm{CO}_{2}$. Culture medium was added and the incubation was performed at $37^{\circ} \mathrm{C}$ and $5 \% \mathrm{CO}_{2}$ for 6 to 7 days, reading every day; another two blind passages were performed if the cytopathic effect (CPE) was not observed. Then, monolayers were subjected to three cycles of freezing-thawing, centrifuged at low speed $\left(1.500 \times \mathrm{g}\right.$ for $10 \mathrm{~min}$ at $\left.4^{\circ} \mathrm{C}\right)$ and the supernatant was tested for parvovirus DNA by PCR assays and immunofluorescence, to confirm the presence of the infectious virus.

\section{Direct Immunofluorescence Assay:}

For the immunofluorescence test each sample was inoculated on a glass chamber slide with A72 cells in mitotic status using the EMEM medium. Incubation was performed at $37^{\circ} \mathrm{C}$ and $5 \% \mathrm{CO} 2$ for $1-4$ days, reading every day. After this period the medium was eliminated, the chamber was moved and the slide was dried. Then it was fixed with acetone at $-20^{\circ} \mathrm{C}$ for at least 30 minutes. Thereafter the slide was stained using specific 
monoclonal antibodies against CPV (VMRD, Inc., Pullman, WA, USA) in accordance with the manufacturer's instructions.

\section{RESULTS}

Blood and stool samples, rectal swabs and tissues derived from tested animals were analyzed by means of PCR. Positive PCR amplification (Figure 1 and 2) was obtained for CPV-2 in 265 of the 673 field samples, corresponding to 137 out of 370 dogs. CPV-2 showed a rate of PCR positivity of $39.38 \%$ in the samples, $37 \%$ of the animals tested. Specific fragments for CPV-2c were generated in the 138 PCR products of both CPV-2 assays (555for and 555rev: 500 - 80 bp; VP2-850-Forward and VP21550-Reverse: 369, 275, 56 bp) by PCR-RFLP (Figure 3 and 4). The biomolecular

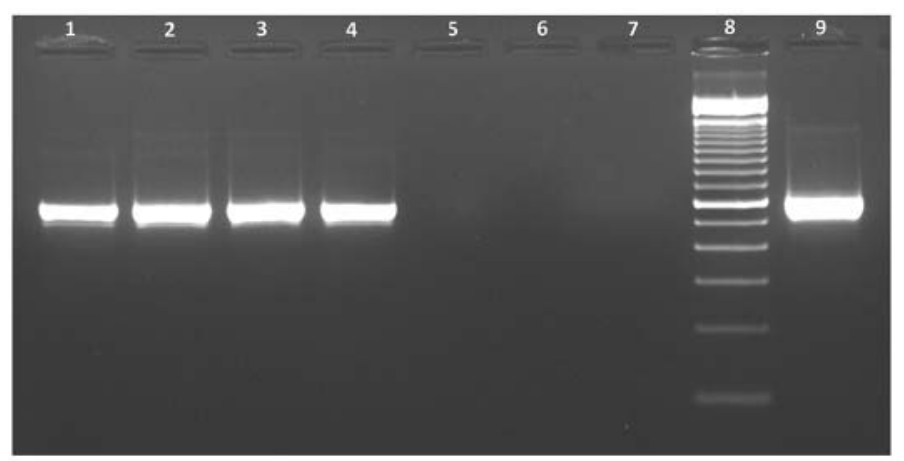

Figure 1. Polymerase Chain Reaction (PCR) Parvovirus - Primers: 555for, 555rev. Lane 1, 2,3 and 4: positive samples; Lane 5: Extraction Control; Lane 6: negative sample; Lane 7: Negative Control; Lane 8: Ladder 100 bp; Lane 9: Positive Control.

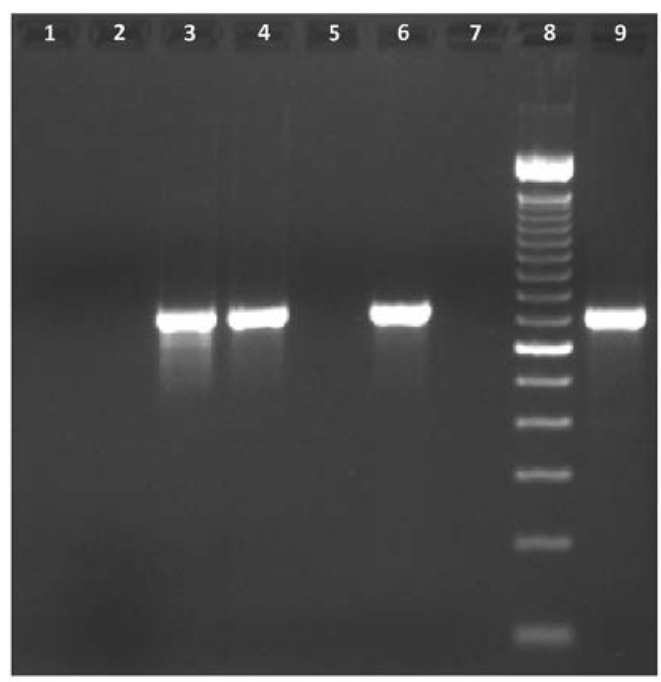

Figure 2. Polymerase Chain Reaction (PCR) Parvovirus - Primers: VP2-850-Forward, VP2-1550-Reverse. Lane 1 and 2: negative samples; Lane 3, 4 and 6: positive samples; Lane 5: Extraction Control; Lane 7: Negative Control; Lane 8: Ladder 100 bp; Lane 9: Positive Control. 
characterization of CPV-2 strains showed that the CPV-2c variant is the most frequent type detected in positive samples (52.07\%). The CPV-2c positive subjects were 109, equal to $79.56 \%$ of the total. Sequences of $1745 \mathrm{nt}$ were obtained from sequencing PCR amplifications. It covers almost the full-length (1755 nt) of the CPV VP2 gene. On the basis of aa residue Glu at residue 426, sequenced strains were characterized as CPV-2a (3 strains) and CPV-2c (27 strains), confirming the related RFLP results.

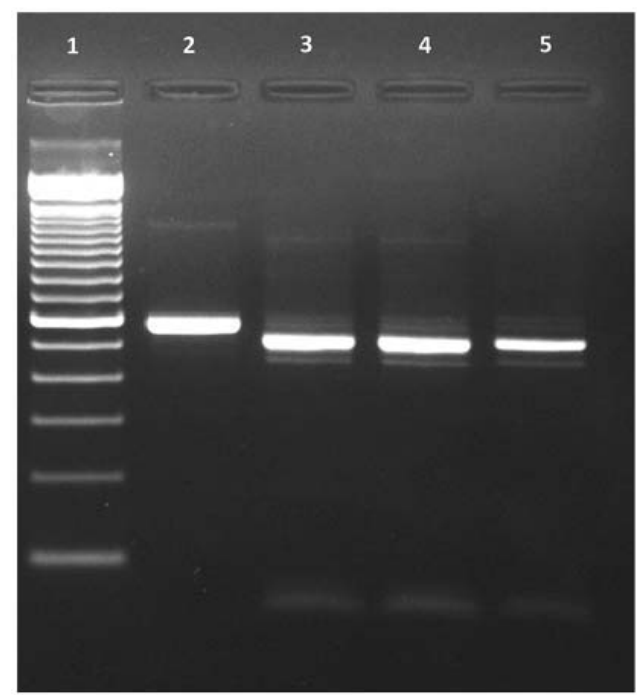

Figure 3. Canine Parvovirus Restriction Fragment Length Polymorphism (CPV RFLP) - Primers: 555for, 555rev with MboII enzyme. Lane 1: Ladder 100 bp; Lane 2: CPV-2, 2a or 2b positive samples; Lane 3, 4 and 5: CPV-2c positive samples.

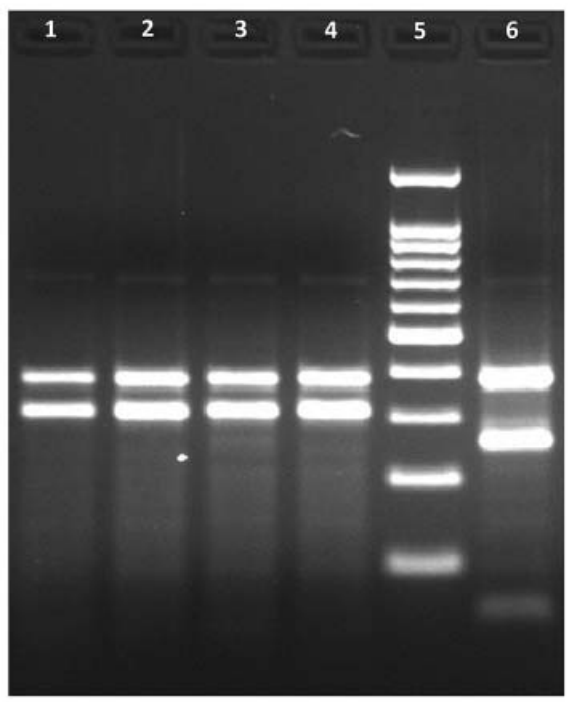

Figure 4. Canine Parvovirus Restriction Fragment Length Polymorphism (CPV RFLP) - Primers: VP2850-Forward, VP2-1550-Reverse with MboII enzyme. Lane 1, 2, 3 and 4: CPV-2, 2a or 2b positive sample; Lane 5: Ladder 100 bp; Lane 6: CPV-2c positive samples. 


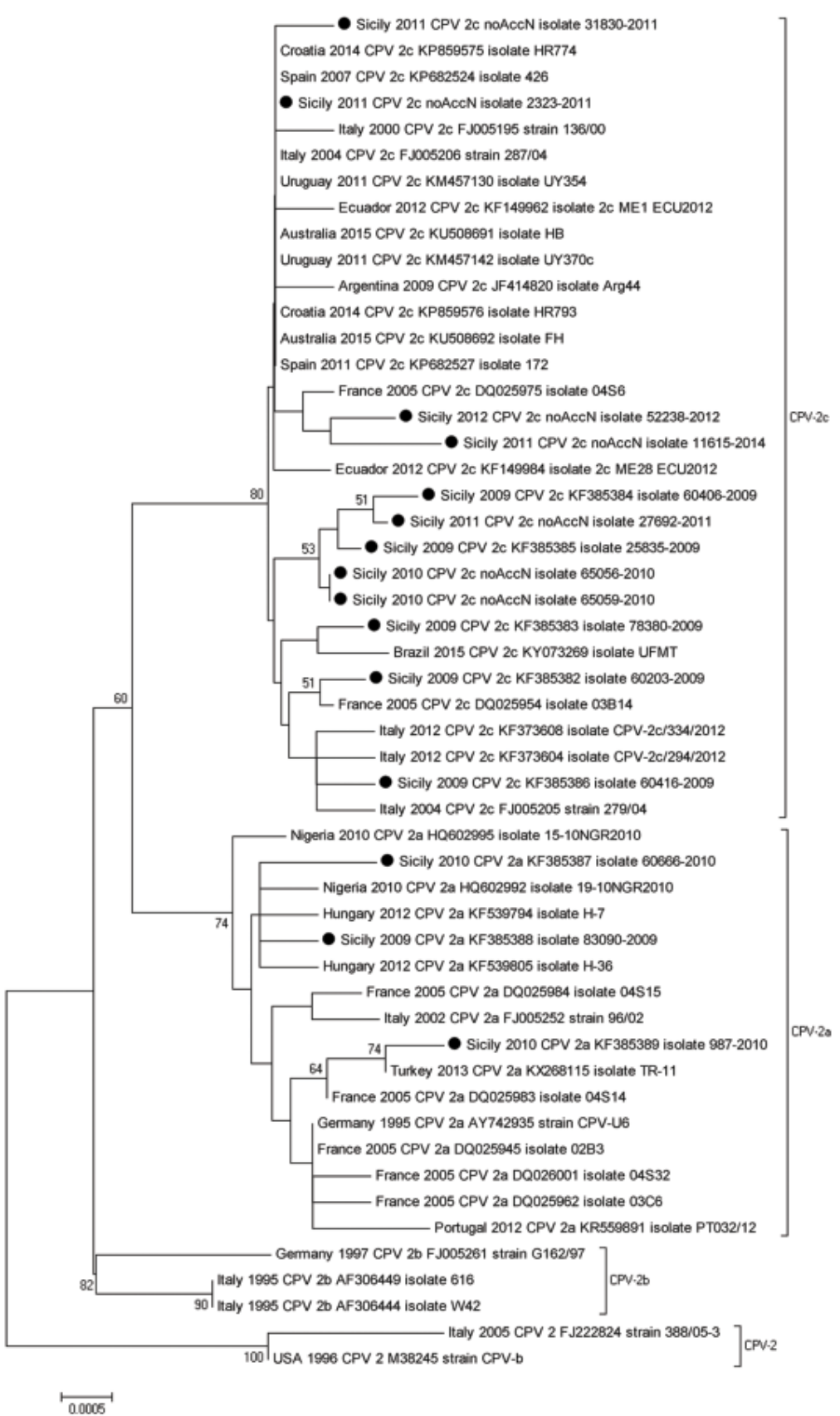

Figure 5. Neighbour-Joining tree based on an nucleotides (nt 1-1745) fragment of VP2 gene sequences of canine parvovirus (CPV) displaying the genetic relationships between CPV strains collected from Sicily and 37 CPV strains/isolates of CPV-2/2a/2b/2c types retrieved from Genbank (bootstrap 1000 replicates; bootstrap values shown greater than 50\%). Black dots markings $(\bullet)$ indicates CPV strains included in this study. CPV strains/isolates were indicated with: country/region (Sicily) and year of collection, CPV type, accession number (if available; where not available is defined as "noAccN"), name of strain/isolate. 
Phylogenetic analysis indicated that strains collected in Sicily segregate into distinct branches, according to their type (CPV-2a, CPV-2c) (Figure 5). Both types are related to CPV-2 strains both from Europe and from non-European countries (Brazil, Turkey, Nigeria), clustering in common clades. Five sequenced strains collected in 2009-2011 (isolates 25835-2009, 60406-2009, 65056-2010, 65059-2010, 27692-2011) segregated in a separate clade within the branch clustering the CPV-2c type sequences. From the total of positive samples inoculated into cell lines, 69.81\% have been isolated (Figure 6) and confirmed by immunofluorescence (Figure 7). Other viral agents from the CPV negative specimens were recovered.

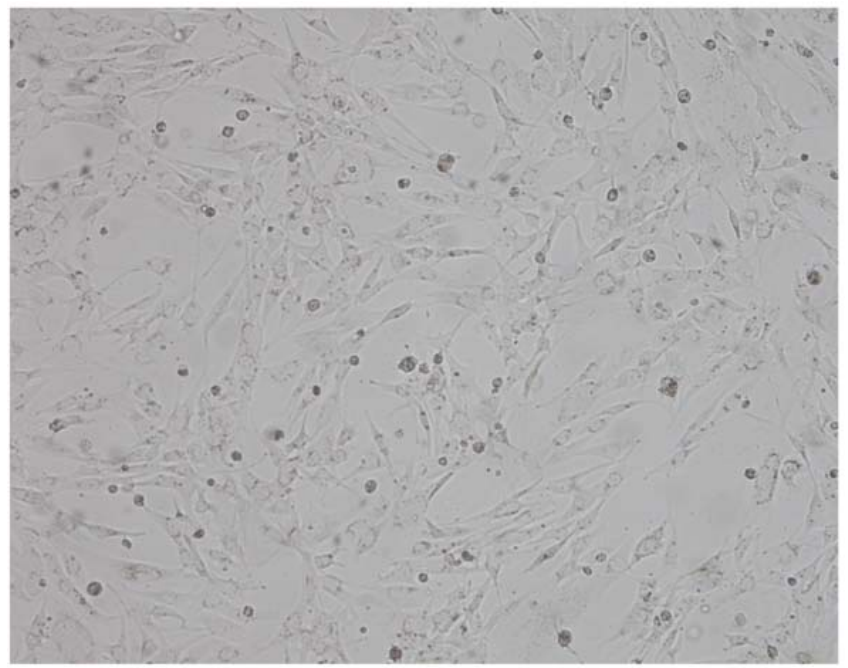

Figure 6. Parvovirus cytopathic effect (CPE) in A72 cell line (100X).

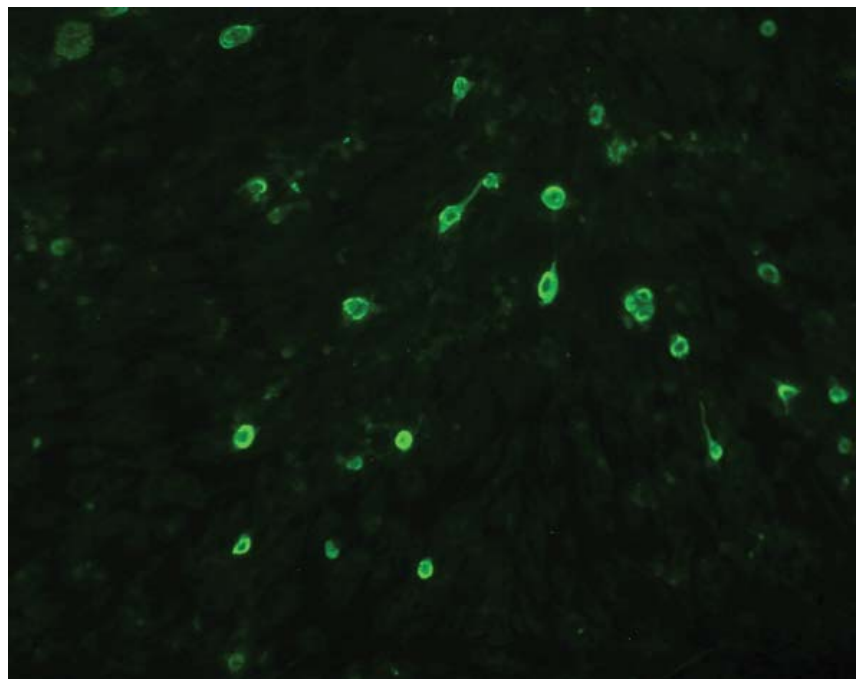

Figure 7. Canine Parvovirus (CPV) positive sample by immunofluorescence (100X). 


\section{DISCUSSION}

Biomolecular methods for the diagnosis of viral diseases allow obtaining a genetic characterization of isolated virus strains that represent a primary step to increase our information about the viral circulation, also providing a more detailed knowledge of viral circulating subtypes. These data are very important in order to perform a correct vaccination strategy, also considering the great ability of viruses in evolving. Viruses as CPV have a high capacity of recombination and evolution, and some subtypes are capable to cause diseases in different species, through cross-species infection $[34,35]$. So, a close monitoring of the virus circulation into an animal population by molecular techniques could be a useful system for the protection of public health, both human and animal.

The use of RFLP and sequencing allows the discrimination of the subtypes of a studied virus, distinguishing for example vaccine strains from wild type strains. Currently licensed vaccines widely used for the control of parvovirosis in Italy are modified live virus (MLV) vaccines based on the original virus type CPV-2 and on the CPV-2b type. Despite the intramuscular or subcutaneous route of administration, vaccine CPV strains are shed in the feces [36]. This could interfere with the PCR diagnosis, leading to false-positive results in recently vaccinated animals. PCR analysis combined with the RFLP-test, as applied in the present study, allow to obtain a rapid discrimination of CPV-2c type [16,18], not included in current vaccines, from other CPV-2 types. This molecular approach can lead to the exclusion of diagnostic doubts in recently vaccinated dogs tested positive to CPV-2c. Alternatively, a minor groove binder (MGB) probe assay could lead to the rapid discrimination between the vaccine and wild type CPV stains or the use of combined methods [36,37]. Further typing of positive samples not digested by MboII enzyme could be obtained using mainly two different molecular approaches: the sequence analysis of PCR products or a molecular approach (Real-Time) based on a MGB probe assay [16,38]. Despite Real-Time assays allow a rapid and unambiguous characterization of CPV-2, sequence analysis additionally leads to discriminate the CPV genotypes and to obtain epidemiological data of wild CPV strains. Additionally it helps to detect any nucleotide/amino acid changes and to obtain the complete genome or gene sequences useful for comparisons trough the sequences database. This approach is supported also by similar studies underlining that in some cases the PCR assays must be related to sequence analysis for a correct identification of variant strains of the virus [16,18,21].

Moreover, it has been reported that DNA viruses such as CPV, likewise RNA viruses, show a high rate of nucleotides during replication [39]. This higher mutation rate, together with non-effective levels of neutralizing antibodies due to an incomplete vaccination, could contribute to the emergence of new viral variants.

In the present study, the main cause of viral enteritis in enrolled dogs was a CPV, specifically the recently evolved worldwide subtype CPV-2c. The CPV-2c variant emerged in the south of Italy in 2000 [18] and rapidly spread throughout Italy [40] and 
all over the world $[41,42]$. A large scale study on CPV types collected from diarrheic dogs in Italy in 1995-2005 observed that the CPV-2a and CPV-2c types were the most prevalent $(64.73 \%$ and $23.43 \%)$ in Italy [38] while subsequent epidemiological surveys showed that CPV-2c type became predominant a few years later (CPV-2a: $45.2 \%$ and CPV-2c: 50\%) [41]. Our results evidenced a different prevalence of CPV-2c type in a long term molecular survey, amounting a higher rate (79.56\%) of CPV-2c type among the dog population. The CPV variants coexist in different ratios in dog populations around the world [43] and can vary according to the geographic region analyzed and the time of sample collection [42]. Despite there is likely no strong evolutionary advantage for any of the CPV types [44], reasons of high prevalence of CPV-2c type in Sicily could involve multiple aspects such as the high resistance of the CPV in the environment, the population immunization rate, the canine movements due to commercial or not-commercial intents, the occurrence of stray dog populations and the long term shedding of CPV after recovery. Despite the current CPV vaccine strains are able to protect against the known CPV-2c variant [45-47], due to the high rate of CPV-2c type associated with disease in dogs evidenced in this study, new vaccines using the CPV variants circulating in the field [35] could be suggested.

Phylogenetic analysis evidenced the close connection of VP2 sequences analyzed in the current study with related strains circulating worldwide and together with the recent evidence of the introduction in Europe of a CPV-2c strain from Asia [48], underline the opportunity of a continuous epidemiological survey trough molecular methods.

In conclusion, the use of accurate diagnostic methods allows the implementation of the information about the isolated virus strains and supports the clinician in achieving prophylactic and therapeutic strategies.

\section{Author's contributions}

GP, FM and SD carried out the molecular genetic studies, participated in the sequence alignment and drafted the manuscript. FM carried out the immunoassays. SD participated in the sequence alignment. EG and SD participated in the design of the study and performed the statistical analysis. AG conceived of the study, and participated in its design and coordination and helped to draft the manuscript. All authors read and approved the final manuscript.

\section{Declaration of conflicting interests}

The author(s) declared no potential conflicts of interest with respect to the research, authorship, and/or publication of this article. 


\section{REFERENCES}

1. Greene C.: Infectious Diseases of the Dog and Cat, 4th Edition. Elsevier Saunders, St. Louis, Missouri, 2012.

2. Pugliese A, Di Pietro S, Giudice E: Clinical and diagnostic patterns of leishmaniasis in the dog. Vet Res Commun 2006, 30:39-43.

3. Giudice E, Di Pietro S, Gaglio G, Di Giacomo L, Bazzano M, Mazzullo G: Adult of Dirofilaria repens in a dog with recurrent multiple subcutaneous nodular lesions. Parasitol Res 2013, 113:711-716.

4. Pérez L, Franca V, Romeo L, Maya L, López I, Hernández M: First detection of canine parvovirus type 2c in South America. Vet Microbiol 2007, 124:147-152.

5. Reed AP, Jones EV, Miller TJ: Nucleotide sequence and genome organization of canine parvovirus. J Virol 1988, 62:266-276.

6. Binn LN, Lazar EC, Eddy GA, Kajima M: Recovery and characterization of a minute virus of canines. Infect Immun 1970, 1:503-508.

7. Battilani M, Ciulli S, Tisato E, Prosperi S: Genetic analysis of canine parvovirus isolates (CPV-2) from dogs in Italy. Virus Res 2002, 83:149-157.

8. Berns KI, Bergoin M, Bloom M, Muzyczka N, Tal J, Tattersall P: Family Parvoviridae. In: Virus Taxonomy. Classification and Nomenclature of Viruses. San Diego: Academic Press; 2000, 311-323.

9. Allison AB, Kohler DJ, Fox KA, Brown JD, Gerhold RW, Shearn-Bochsler VI, Dubovi EJ, Parrish CR, Holmes EC: Frequent Cross-Species Transmission of Parvoviruses among Diverse Carnivore Hosts. J Virol 2013, 87:2342-2347.

10. Truyen U, Platzer G, Parrish CR, Hänichen T, Hermanns W, Kaaden OR: Detection of canine parvovirus DNA in paraffin-embedded tissues by polymerase chain reaction. J Vet Med B Infect Dis Vet Public Health 1994, 41:148-152.

11. Mochizuki M, Hashimoto M, Hajiima T, Takiguchi M, Hashimoto A, Une Y, Roerink F, Ohshima T, Parrish CR, Carmichael LE: Virologic and Serologic Identification of Minute Virus of Canines (Canine Parvovirus Type 1) from Dogs in Japan. J Clin Microbiol 2002, 40:3993-3998.

12. Pratelli A, Buonavoglia D, Tempesta M, Guarda F, Carmichael L, Buonavoglia C: Fatal canine parvovirus type-1 infection in pups from Italy. J Vet Diagn Invest 1999, 11:365-367.

13. Carmichael LE, Schlaffer DH, Hashimoto A: Minute virus of canines (MVC, canine parvovirus type-1): pathogenicity for pups and seroprevalence estimate. J Vet Diagn Invest 1994, 6:167-174.

14. Parrish CR, Aquadro CF, Strassheim ML, Evermann JF, Sgro JY, Mohammed HO: Rapid antigenic-type replacement and DNA sequence evolution of canine parvovirus. J Virol 1991, 65:6544-6552.

15. Parrish CR, O'Connell PH, Evermann JF, Carmichael LE: Natural variation of canine parvovirus. Science 1985, 230:1046-1048.

16. Decaro N, Elia G, Campolo M, Desario C, Lucente MS, Bellacicco AL, Buonavoglia C: New approaches for the molecular characterization of Canine Parvovirus Type 2 Strains. J Vet Med 2005, 52:316-319.

17. Decaro N, Elia G, Martella V, Desario C, Campolo M, Trani LD, Tarsitano E, Tempesta M, Buonavoglia C: A real-time PCR assay for rapid detection and quantification of canine parvovirus type 2 DNA in the feces of dogs. Vet Microbiol 2005, 105:19-28. 
18. Buonavoglia C, Martella V, Pratelli A, Tempesta M, Cavalli A, Buonavoglia D, Bozzo G, Elia G, Decaro N, Carmichael L: Evidence for evolution of canine parvovirus type-2 in Italy. J Gen Virol 2001, 82:3021-3025.

19. Cavalli A, Bozzo G, Decaro N, Tinelli A, Aliberti A, Buonavoglia D: Characterization of a canine parvovirus strain isolated from an adult dog. New Microbiol 2001, 24:239-242.

20. Nakamura M, Tohya Y, Miyazawa T, Mochizuki M, Phung HT, Nguyen NH, Huynh LM, Nguyen LT, Nguyen PN, Nguyen PV, Nguyen NP, Akashi H: A novel antigenic variant of canine parvovirus from Vietnamese dog. Arch Virol 2004, 149:2261-2269.

21. Decaro N, Martella V, Desario C, Bellacicco AL, Camero M, Manna L, d'Aloja D, Buonavoglia C: First detection of canine parvovirus type $2 \mathrm{c}$ in pups with haemorragic enteritis in Spain. J Vet Med B Infect Dis Vet Public Health 2006, 53:468-472.

22. Hong C, Decaro N, Desario C, Tanner P, Pardo MC, Sanchez S, Buonavoglia C, Saliki JT: Occurence of canine parovirus type 2c in the United States. J Vet Diagn Invest 2007, 19:535-539.

23. Touihri L, Bouzid I, Daoud R, Desario C, El Goulli AF, Decaro N, Ghorbel A, Buonavoglia C, Bahloul C: Molecular characterization of canine parvovirus-2 variants circulating in Tunisia. Virus Genes 2009, 38:249-258.

24. Calderón MG, Mattion N, Bucafusco D, Fogel F, Remorini P, La Torre J: Molecular characterization of canine parvovirus strains in Argentina: Detection of the pathogenic variant CPV2c in vaccinated dogs. J Virol Methods 2009, 159:141-145.

25. Calderón MG, Romanutti C, D’Antuono A, Keller L, Mattion N, La Torre J: Evolution of canine parvovirus in Argentina between years 2003 and 2010: CPV2c has become the predominant variant affecting the domestic dog population. Virus Res 2011, 157:106-110.

26. Hoffmann B, Beer M, Reid SM, Mertens P, Oura CA, van Rijn PA, Slomka MJ, Banks J, Brown IH, Alexander DJ, King DP: A review of RT-PCR technologies used in veterinary virology and disease control: sensitive and specific diagnosis of five livestock diseases notifiable to the World Organisation for Animal Health. Vet Microbiol 2009, 139:1-23.

27. Daniels JB: Molecular Diagnostics for Infectious Disease in Small Animal Medicine: An Overview from the Laboratory. Vet Clin North Am Small Anim Pract 2013, 43:1373-1384.

28. Battilani M, Scagliarini A, Tisato E, Turilli C, Jacoboni I, Casadio R, Prosperi S: Analysis of canine parvovirus sequences from wolves and dogs isolated in Italy. J Gen Virol 2001, 82:1555-1560.

29. Mochizuki M, Horiuchi M, Hiragi H, San Gabriel MC, Yasuda N, Uno T: Isolation of canine parvovirus from a cat manifesting clinical signs of feline panleukopenia. J Clin Microbiol 1996, 34:2101-2105.

30. Truyen U, Muller T, Heidrieh R, Tackmann K, Carmichael LE: Survey on viral pathogens in wild red foxes (Vulpes vulpes) in Germany with special emphasis on parvoviruses and analysis of a DNA sequence from a red fox parvovirus. Epidemiol Infect 1998, 121:433440.

31. Hall TA: BioEdit: a user-friendly biological sequence alignment editor and analysis program for Windows 95/98/NT. Nucl Acids Symp Ser 1999, 41:95-98.

32. Tamura K, Peterson D, Peterson N, Stecher G, Nei M, Kumar S: MEGA5: molecular evolutionary genetics analysis using maximum likelihood, evolutionary distance, and maximum parsimony methods. Mol Biol Evol 2011, 28:2731-9. doi: 10.1093/molbev/ msr121.

33. Binn LN, Marchwicki RH, Stephenson EH: Establishment of a canine cell line: derivation, characterization and viral spectrum. Am J Vet Res 1980, 41:855-860. 
34. Decaro N, Desario C, Amorisco F, Losurdo M, Colaianni ML, Greco MF, Buonavoglia C: Canine Parvovirus type 2c infection in a kitten associated with intracranial abscess and convulsions. J Feline Med Surg 2011, 13: 231-236.

35. Decaro N, Desario C, Elia G, Martella V, Mari V, Lavazza A, Nardi M, Buonavoglia C: Evidence for immunization failure in vaccinated adult dogs infected with canine parvovirus type 2c. New Microbiol 2008, 31:125-130.

36. Decaro N, Elia G, Desario C, Roperto S, Martella V, Campolo M, Lorusso A, Cavalli A, Buonavoglia C: A minor groove binder probe real-time PCR assay for discrimination between type 2-based vaccines and field strains of canine parvovirus. J Virol Methods 2006, 136:65-70.

37. Decaro N, Martella V, Elia G, Desario C, Campolo M, Buonavoglia D, Bellacicco AL, Tempesta M, Buonavoglia C: Diagnostic tools based on minor groove binder probe technology for rapid identification of vaccinal and field strains of canine parvovirus type 2b. J Virol Methods 2006, 138:10-16.

38. Decaro N, Elia G, Martella V, Campolo M, Desario C, Camero M, Cirone F, Lorusso E, Lucente MS, Narcisi D, Scalia P, Buonavoglia C: Characterisation of the canine parvovirus type 2 variants using minor groove binder probe technology. J Virol Methods 2006, 133:9299.

39. Shackelton LA, Parrish CR, Truyen U, Holmes EC: High rate of viral evolution associated with the emergence of carnivore parvovirus. Proc Natl Acad Sci USA. 2005, 102:379-384.

40. Martella V, Cavalli A, Pratelli A, Bozzo G, Camero M, Buonavoglia D, Narcisi D, Tempesta M, Buonavoglia C: A Canine Parvovirus Mutant Is Spreading in Italy. J Clin Microbiol 2004, 42:1333-1336.

41. Decaro N, Buonavoglia C: Canine parvovirus-A review of epidemiological and diagnostic aspects, with emphasis on type 2c. Vet Microbiol 2012, 155: 1-12.

42. Miranda C, Thompson G: Canine parvovirus: the worldwide occurrence of antigenic variants. J Gen Virol 2016, 97: 2043-2057.

43. Truyen U, Evermann JF, Vieler E, Parrish CR: Evolution of canine parvovirus involved loss and gain of feline host range. Virology 1996, 215:186-189.

44. Steinel A, Venter EH, Van Vuuren M, Parrish CR, Truyen U: Antigenic and genetic analysis of canine parvoviruses in southern Africa. Onderstepoort J Vet Res 1998, 65: 239-242.

45. Larson LJ, Schultz RD: Do two current canine parvovirus type 2 and $2 \mathrm{~b}$ vaccines provide protection against the new type 2c variant? Vet Ther 2008, 9:94-101.

46. Spibey N, Greenwood NM, Sutton D, Chalmers WSK, Tarpey I: Canine parvovirus type 2 vaccine protects against virulent challenge with type 2c virus. Vet Microbiol 2008, 128:4855.

47. Wilson S, Stirling C, Borowski S, Thomas A, King V, Salt J: Vaccination of dogs with Duramune DAPPi+LC protects against pathogenic canine parvovirus type $2 \mathrm{c}$ challenge. Vet Rec 2013, 172:662.

48. Mira F, Purpari G, Lorusso E, Di Bella S, Gucciardi F, Desario C, Macaluso G, Decaro $\mathrm{N}$, Guercio A: Introduction of Asian canine parvovirus (CPV) in Europe through dog importation. Transbound Emerg Dis 2017, in press. 


\section{ISPITIVANJE CIRKULACIJE PARVOVIRUSA KOD POPULACIJE PASA IZ SICILIJE BIOMOLEKULARNIM METODAMA}

PURPARI Giuseppa ${ }^{1}$, MIRA Francesco, Di BELLA Santina, Di PIETRO Simona, GIUDICE Elisabetta, GUERCIO Annalisa

Parvovirus pasa- tip 2 (CPV-2) je DNK virus koji izaziva infektivno oboljenje pasa u celom svetu. Od kada je prvi put izolovan, CPV-2 je evoluirao pri čemu su ustanovljene nove genetske i antigene varijante (CPV-2a, 2b, 2c) koje su distribuirane globalno. U studiji je ispitivana incidencija CPV-2 u populaciji pasa Sicilije (Italija) lančanom reakcijom polimeraze (PCR) koristećenjem fragmenta VP2 gena virusa. Od ukupno 673 uzorka, poreklom od 370 pasa, koji su laboratorijski ispitani od jula 2009. do augusta 2015. godine, ukupno je 265 uzoraka (39,38\%) bilo pozitivno. Ovi su uzorci dalje ispitivani pomoću polimorfizam restriktivne dužine fragmenta (RFLP), a obavljeno je i sekvenciranje gena virusa. Uočena je visoka prevalencija CPV-2c $(79,56 \%$ CPV-2 pozitivnih pasa) što ukazuje na činjenicu da je ovaj tip virusa dominantan i cirkuliše kod pasa na Siciliji. Sekvencioniranje kao i filogenetska analiza ukazuju na blisku povezanost između CPV-2a i CPV-2c sojeva u Evropi i vanevropskim zemljama. S obzirom na globalnu distribuciju CPV-2c kao i na činjenicu da od ovog soja virusa oboljevaju i vakcinisane životinje, neophodno je da se obave istraživanja i učine napori u smeru razvoja novih CPV vakcina. 